\title{
Valor Nutritivo do Capim-Tanzânia (Panicum maximum Jacq. cv. Tanzânia-1) Pastejado em Diferentes Alturas ${ }^{1}$
}

\author{
Clovenilson Cláudio Perissato Cano ${ }^{2}$, Ulysses Cecato ${ }^{3}$, Marcos Weber do Canto ${ }^{3}$, Geraldo \\ Tadeu dos Santos ${ }^{3}$, Sandra Galbeiro ${ }^{5}$, Elias Nunes Martins ${ }^{3}$, Rodrigo Távora Mira ${ }^{4}$
}

RESUMO - Avaliaram-se as concentrações de proteína bruta (PB), de fibra em detergente neutro (FDN), de fibra em detergente ácido (FDA), de fósforo (P), de potássio (K), de cálcio (Ca) e de magnésio $(\mathrm{Mg})$ e a digestibilidade in vitro da matéria seca (DIVMS) nas frações lâminas foliares e colmos + bainhas em pastagem de capim-Tanzânia (Panicum maximum Jacq. cv. Tanzânia-1) manejada em quatro alturas de dossel forrageiro (20, 40, 60 e 80 cm). O método de pastejo foi o de lotação contínua, com taxa de lotação variável, e os animais utilizados foram novilhos da raça Nelore, com peso médio de $340 \mathrm{~kg}$. Utilizou-se o delineamento experimental inteiramente casualizado com duas repetições, sendo realizadas cinco avaliações no período (112 dias). O aumento na altura do dossel promoveu redução nas concentrações de PB, Ca, P, Mg e DIVMS e elevação nas concentrações de FDN, FDA e K para as frações lâmina foliar e colmo + bainha. As lâminas foliares apresentaram melhor composição química que colmos + bainhas em todas as alturas de dossel e em todos os períodos de avaliação. A altura de dossel de 40 a 50 cm propiciou boa composição química e DIVMS.

Palavras-chave: DIVMS, fibra em detergente neutro, fibra em detergente ácido, minerais, proteína bruta

\section{Nutritive Value of Tanzaniagrass (Panicum maximum Jacq. cv. Tanzânia-1) Grazed at Different Heights}

\begin{abstract}
Crude protein (CP), neutral detergent fiber (NDF), acid detergent fiber (ADF), phosphorus (P), potassium (K), calcium (Ca), magnesium (Mg) and in vitro dry matter digestibility (IVDMD) contents were assessed in the leaf blade and stem + leaf sheath fractions of Tanzaniagrass (Panicum maximum Jacq. cv. Tanzania-1) managed at four sward heights (20, 40, 50 and $65 \mathrm{~cm}$ ). The grazing method was the continuous stocking and variable stocking rate, and used Nelore steers with an average weight of $340 \mathrm{~kg}$. The completely randomized experimental design was used with two replications, and five evaluations were performed during a period of 112 days. The CP, IVDMD, $\mathrm{Ca}, \mathrm{P}$ and Mg contents decreased while NDF, ADF and K concentrations increased in the leaf blade and stem + leaf sheath fraction in response to grazing height as well as period of evaluation. Leaf blades exibited higher quality than stem + leaf sheath regardless of grazing height and evaluation time. Tanzaniagrass grazed to 40 and $50 \mathrm{~cm}$ presents good chemical composition and IVDMD.
\end{abstract}

Key Words: IVDMD, crude protein, acid detergent fiber, neutral detergent fiber, mineral

\section{Introdução}

As plantas forrageiras variam quanto à estrutura da vegetação, em função da arquitetura da planta, do hábito e estádio de crescimento, das condições edafoclimáticas e do efeito dos animais. A produtividade e a estrutura do dossel forrageiro podem ser influenciadas pelo manejo e, principalmente, pelas diferentes freqüências e alturas de pastejo utilizadas.

Tradicionalmente, as pastagens da região noroeste do Paraná são manejadas inadequadamente, o que, associado à sazonalidade climática, determina a dis- tribuição irregular da produção de forragem ao longo do ano. Nessas condições, ocorrem flutuações acentuadas na quantidade de forragem disponível para os animais ao longo das estações que, por sua vez, podem ocasionar variações no desempenho individual e por área. Para amenizar essa situação, há a necessidade de se manter a pastagem sempre com nível adequado de massa de forragem. Neste aspecto, a altura do dossel forrageiro pode se constituir numa orientação adequada no monitoramento da massa de forragem na pastagem (Hodgson, 1990; Hepp et al., 1996; Canto et al., 2001).

\footnotetext{
1 Parte integrante da dissertação do primeiro autor.

2 Mestre em Zootecnia - UEM (canozoo@hotmail.com).

${ }^{3}$ Professores do Departamento de Zootecnia - UEM. Av. Colombo, 5.790, 87020-900, Maringá-PR. Pesquisadores do CNPq (ucecato@uem.br)

4 Médico Veterinário da PUC-PR.

${ }^{5}$ Acadêmica de Pós-Graduação - Mestrado, PPZ - UEM.
} 
O valor nutritivo das plantas forrageiras tem sido avaliado por meio da composição química da forragem e de sua digestibilidade, pela determinação das porcentagens de proteína bruta (PB), fibra em detergente neutro (FDN), fibra em detergente ácido (FDA), lignina e da digestibilidade in vitro da matéria seca. Entretanto, existem diferenças entre as frações que compõem a estrutura da planta. Segundo Minson (1990) e Van Soest (1994), as folhas apresentam maior teor de PB e menores teores de FDN, de FDA e de lignina que os caules ou colmos das plantas forrageiras. Zimmer (1999), trabalhando com níveis de nitrogênio e resíduos de massa de forragem após pastejo, observou menores teores de FDN e de FDA, teor mais elevado de PB e maior digestibilidade nas folhas que nos colmos, sobretudo nos estratos intermediários e superiores do dossel forrageiro.

A massa de forragem da pastagem exerce efeito importante na qualidade da forragem por modificar a estrutura do dossel, alterando a proporção dos componentes folha, colmo e material morto (Bortolo, 1999). A composição química e a digestibilidade in vitro da forragem em pastagem de Coastcross-1 (Cynodon dactylon (L.) Pers), sob diferentes níveis de matéria seca residual (MSR), apresentaram decréscimos lineares nos teores de FDN e de FDA com o aumento da MSR. A DIVMS apresentou aumento linear em relação aos níveis de MSR e decréscimo linear com o passar das datas de amostragem. Os teores de PB na forragem não foram alterados em função dos níveis de RMS ao longo do período de avaliação.

Em capim-Tanzânia manejado segundo alturas do dossel forrageiro sob pastejo, Rego (2001) observou redução da concentração de PB e aumento nas concentrações de FDA e de FDN, tanto para lâminas quanto para colmos, em resposta aos avanços na altura do dossel. Todavia, a DIVMS das lâminas não foi influenciada pela altura do dossel. No mesmo trabalho, o aumento na altura do dossel proporcionou maiores concentrações de Ca e menores de Mg nas lâminas, enquanto, nos colmos, houve redução nos teores de $\mathrm{P}$ e de Mg. Ao longo do período experimental, houve aumento dos teores de Ca e de $\mathrm{Mg}$ e redução de K e de P nas frações lâminas e colmos.

Euclides et al. (1996) obtiveram concentrações de PB no capim-Tanzânia-1 de 6,8\% na MS da massa de forragem verde (2,5 t/ha em média) ao longo de três anos quando manejado sob pastejo contínuo. Valores superiores foram encontrados por Machado et al. (1998) para PB no capim-Tanzânia sob duas alturas de corte (20 e $40 \mathrm{~cm}$ ). Por outro lado, Gerdes et al. (2000) obtiveram porcentagens para PB de 13,7; 10,8; 19,8 e 15,3 em folhas de capim-Tanzânia nas estações primavera, verão, outono e inverno, respectivamente. As concentrações de PB da fração lâmina foliar foram superiores às do colmo em todas as estações avaliadas. No mesmo trabalho, o teor médio de FDN, no verão, foi de 78,1\% e a DIVMS de $61,0 \%$ para a planta inteira.

Trabalhando com pastagem de capim-elefante anão (Pennisetum purpureum Schum. cv. Mott) submetida a níveis de oferta de forragem, sob lotação contínua, Almeida et al. (2000) observaram relação inversa entre a porcentagem de PB e DIVMS e a oferta de forragem (OF), porém as porcentagens de FDN e de FDA aumentaram com a oferta de forragem.

Objetivou-se, com este estudo, avaliar o efeito das alturas de dossel forrageiro de 20, 40, 60 e $80 \mathrm{~cm}$ e do período de coleta sobre os teores de PB, FDN, FDA, composição mineral e a digestibilidade in vitro da forragem em pastagem de capim-Tanzânia (Panicum maximum Jacq. cv. Tanzânia-1) submetida a pastejo com lotação contínua.

\section{Material e Métodos}

O experimento foi conduzido em uma área pertencente à Fazenda Nossa Senhora Aparecida, localizada no município de Astorga, região noroeste do Paraná, no período de 23 de dezembro de 1999 a 29 de abril de 2000.

O clima da região é "Cfa", subtropical úmido, mesotérmico com verões quentes e geadas pouco freqüentes (Corrêa, 1996). As coordenadas geográficas aproximadas do local do experimento são $51^{\circ} 57^{\prime}$ de longitude, $23^{\circ} 25^{\prime}$ de latitude e $545 \mathrm{~m}$ de altitude. Os dados de temperatura e de precipitação pluviométrica (máxima, mínima e média) estão resumidos na Tabela 1.

O solo da área experimental é do tipo Latossolo Vermelho Eutroférrico, com as seguintes características de fertilidade: $\mathrm{pH}-\mathrm{H}_{2} \mathrm{O}=6,9, \mathrm{Al}^{+++}=0,00^{*}, \mathrm{H}^{+}$ $+\mathrm{Al}^{+++}=3,13^{*}, \mathrm{Ca}^{++}+\mathrm{Mg}^{++}=7,16^{*}, \mathrm{Ca}^{++}=5,88^{*}$, $\mathrm{K}^{+}=0,60 \mathrm{cmolcdm}^{-3}(*), \mathrm{P}=3 \mathrm{mgdm}^{-3}$ e C $=15,96 \mathrm{gdm}^{-3}$. Por ocasião da semeadura da pastagem, foram aplicados $180 \mathrm{~kg} / \mathrm{ha}$ de $\mathrm{P}_{2} \mathrm{O}_{5}$ e $60 \mathrm{~kg} /$ ha de $\mathrm{K}_{2} \mathrm{O}$, enquanto, no período de dezembro de 1998 a março de 1999, $250 \mathrm{~kg} / \mathrm{ha}$ de $\mathrm{N}$ na forma de uréia, parcelados em quatro vezes $(50,80,70$ e $50 \mathrm{~kg} / \mathrm{ha}$ de $\mathrm{N}$, nos meses

R. Bras. Zootec., v.33, n.6, p.1959-1968, 2004 (Supl. 2) 
Tabela 1 - Precipitação pluviométrica e temperaturas médias durante o período experimental Table 1 - Mean temperature and rainfall, during the experimental period

\begin{tabular}{|c|c|c|c|c|}
\hline \multirow[t]{2}{*}{$\begin{array}{l}\text { Mês } \\
\text { Month }\end{array}$} & \multirow[t]{2}{*}{$\begin{array}{l}\text { Precipitação (mm) } \\
\quad \text { Rainfall }(\mathrm{mm})\end{array}$} & \multicolumn{3}{|c|}{$\begin{array}{l}\text { Temperatura }\left({ }^{\circ} \mathrm{C}\right) \\
\text { Temperature }\left({ }^{\circ} \mathrm{C}\right)\end{array}$} \\
\hline & & $\begin{array}{l}\text { Máxima } \\
\text { Maximum }\end{array}$ & $\begin{array}{l}\text { Mínima } \\
\text { Minimum }\end{array}$ & $\begin{array}{l}\text { Média } \\
\text { Mean }\end{array}$ \\
\hline Novembro/99 (November 99) & 46,7 & 29,3 & 17,4 & 24,5 \\
\hline Dezembro/99 (December 99) & 280,9 & 31,0 & 20,0 & 26,6 \\
\hline Janeiro/2000 (January 00) & 242,8 & 31,0 & 20,6 & 26,4 \\
\hline Fevereiro/2000 (February 00) & 278,4 & 28,9 & 20,2 & 25,2 \\
\hline Março/2000 (March 00) & 130,3 & 29,0 & 19,8 & 24,7 \\
\hline Abril/2000 (April 00) & 32,0 & 29,1 & 18,8 & 24,4 \\
\hline
\end{tabular}

Fonte: Estação Climatológica Principal de Maringá.

de dezembro, janeiro, fevereiro e março, respectivamente). Em outubro de 1999, foram aplicados $300 \mathrm{~kg} / \mathrm{ha}$ da fórmula 0-20-20 (NPK) e mais $600 \mathrm{~kg} / \mathrm{ha}$ de superfosfato simples para adubação de $180 \mathrm{~kg} / \mathrm{ha}$ de $\mathrm{P}_{2} \mathrm{O}_{5}$ e $60 \mathrm{~kg} / \mathrm{ha}$ de $\mathrm{K}_{2} \mathrm{O}$. No período de dezembro de 1999 a fevereiro de 2000, foram aplicados $250 \mathrm{~kg} / \mathrm{ha}$ de $\mathrm{N}$, na forma de uréia, em quatro parcelas (50, 80, 70 e $50 \mathrm{~kg} / \mathrm{ha}$ de $\mathrm{N}$, nos meses de dezembro, janeiro, início e final de fevereiro, respectivamente).

Este experimento foi conduzido em área já estabelecida de capim-Tanzânia em setembro de 1998 e dividida em oito unidades experimentais (piquetes), com área variável de 1,04 ha a 1,27 ha, ocupando área total de 8,9 ha. Cada piquete possuía cochos para sal mineral e reservatório de água. Uma área de 6,0 ha, adjacente à área experimental e com o mesmo cultivar de gramínea forrageira, foi destinada à manutenção dos animais reguladores da condição dos tratamentos experimentais.

Os tratamentos estudados foram quatro alturas de dossel forrageiro: $\mathrm{T} 1=20 \mathrm{~cm}, \mathrm{~T} 2=40 \mathrm{~cm}$, $\mathrm{T} 3=60 \mathrm{~cm}$ e T4 $=80 \mathrm{~cm}$. Para a análise de regressão, foram utilizadas as alturas médias reais observadas nas unidades experimentais, em cada avaliação. Estes tratamentos foram avaliados sob pastejo contínuo e taxa de lotação variável. O delineamento experimental empregado foi o inteiramente casualizado, com duas repetições, totalizando oito unidades experimentais.

A entrada dos animais na área ocorreu em 23 de dezembro de 1999, sendo a primeira avaliação do pasto efetuada em 04 de janeiro de 2000 (dia zero) e a última em 29 de abril de 2000, correspondendo a um período de 112 dias de avaliação.
O ajuste da taxa de lotação foi feito a cada duas semanas, conforme a altura de dossel requerida em cada unidade experimental. A altura de dossel foi estimada com o auxílio de uma régua de 2,0 $\mathrm{m}$ de comprimento, graduada em centímetros, fazendo-se 50 leituras a cada sete dias em cada unidade experimental. Para a estimativa da altura do dossel, foi considerada a extremidade ou o ponto de curvatura da lâmina da folha mais alta no local da amostragem, a partir do nível do solo.

Os animais utilizados no experimento foram novilhos castrados da raça Nelore, com dois anos e peso vivo médio inicial de $340 \mathrm{~kg}$, provenientes do rebanho da Fazenda Nossa Senhora Aparecida. Foram utilizados quatro animais testers por piquete $\mathrm{e}$ os animais reguladores, que foram colocados ou retirados para a manutenção do nível de altura do dossel, pela técnica put and take para estudo com lotações variáveis (Mott \& Lucas, 1952).

Para determinação da composição química e da DIVMS das frações lâminas foliares verdes e colmos + bainhas verdes, foi colhido material vegetativo em cinco locais de $0,50 \times 0,50 \mathrm{~m}\left(0,25 \mathrm{~m}^{2}\right)$, a cada 28 dias, nas unidades experimentais. $\mathrm{O}$ material colhido foi separado em lâmina verde, colmo + bainha verde e material morto. Logo após, estas amostras foram secas em estufa de circulação de ar forçado por 72 horas a $55^{\circ} \mathrm{C}$. Em seguida, foram pesadas, moídas em peneira de $1,0 \mathrm{~mm}$ e armazenados para análises posteriores.

Nas frações lâmina verde e colmo + bainha verde, determinou-se a porcentagem de proteína bruta (PB), fibra em detergente neutro (FDN), fibra em detergente ácido (FDA), e a porcentagem de $\mathrm{P}, \mathrm{Ca}, \mathrm{Mg}$ e 
K, utilizando-se o equipamento Near Infra Red Spectroscopy (NIRS), conforme Barnes (1980). Essas análises foram realizadas no Departamento de Nutrição Animal da Universidade Federal do Paraná. A digestibilidade in vitro da matéria seca (DIVMS) foi determinada no Laboratório de Nutrição Animal do Departamento de Zootecnia da Universidade Estadual de Maringá, utilizando-se a técnica desenvolvida por ANKOM, conforme Santos et al. (1997).

Os dados experimentais foram avaliados estatisticamente pela análise de regressão, empregando-se o programa SAEG (1993), adotando-se a metodologia de superfície de resposta, a partir do modelo polinomial quadrático, em função das duas variáveis independentes. O modelo estatístico para análise dos resultados do pasto foi:

$\hat{Y}_{i j k}=\mu+b_{1} A_{i}+b_{2} A_{i}{ }^{2}+b_{3} T_{j}+b_{4} T_{j}^{2}+b_{5} A_{i j}+e_{i j k}$

em que $\hat{\mathrm{Y}}_{\mathrm{ijk}}=$ valor estimado das variáveis, no piquete $\mathrm{j}$, recebendo tratamento $\mathrm{i} ; \mu=$ constante geral; $\mathrm{A}=$ altura do dossel; $\mathrm{T}=$ efeito do dia de avaliação; $b_{1}=$ coeficiente linear da regressão da variável $\hat{Y}$, em função da altura do dossel; $b_{2}=$ coeficiente quadrático da regressão da variável $\mathrm{Y}$, em função da altura do dossel; $b_{3}=$ coeficiente linear da regressão da variável $\hat{Y}$, em função do dia de avaliação; $b_{4}=$ coeficiente quadrático da regressão da variável $\hat{Y}$, em função do tempo; $b_{5}=$ coeficiente da variável $\hat{Y}$, em função da interação entre altura e tempo; $\mathrm{e}_{\mathrm{ijk}}=$ erro aleatório associado a cada observação $Y_{i j k}$.

\section{Resultados e Discussão}

As concentrações de proteína bruta nas lâminas foliares verdes (PBL) e os teores de proteína bruta nos colmos + bainhas verdes (PBC) são apresentadas nas Figuras 1 e 2, respectivamente. Ocorreu decréscimo nas concentrações de PBL e PBC com o avanço nas alturas do dossel forrageiro $(\mathrm{P}<0,05)$. A redução nas concentrações de PBC com o aumento em altura do dossel foi influenciada pelo estádio fisiológico das plantas e pelo grau de maturidade, porque plantas mantidas mais altas apresentam colmos mais velhos e mais lignificados, com conseqüente redução das concentrações de proteína bruta (Minson, 1990; Van Soest, 1994). Este comportamento, em parte, está associado à manutenção do pasto mais baixo, favorecendo a constante rebrotação com a manutenção de folhas e colmos jovens e maior número de perfilhos jovens. Nos pastos mantidos mais altos, ocorreu comportamento inverso, pois, nas maiores alturas, a proporção de folhas e colmos jovens é menor em alturas menores. Comportamento semelhante foi observado por Rego (2001) em capimTanzânia manejado segundo diferentes alturas de dossel. Carnevalli et al. (2001), avaliando o desempenho de ovinos e as características do dossel forrageiro de Tifton 85 em pastos mantidos em quatro alturas de dossel, também observaram maior concentração de PB para os pastos mantidos mais baixos.

Quanto ao dia de coleta, o comportamento para PBL (Figura 1) e PBC (Figura 2) foi quadrático $(\mathrm{P}<0,05)$. A elevação nas concentrações de PBL e $\mathrm{PBC}$ até os 56 dias de pastejo pode ser explicada pelo efeito do parcelamento da adubação nitrogenada e maior quantidade aplicada anteriormente. O nitrogênio em pastagens tem efeito direto na produção de MS, aumentando a participação da MS de folhas na MS total, promovendo incremento nos teores de PB (Werner, 1986; Zimmer, 1999). Redução nas concentrações de PBL e PBC, no período final, deve estar associada ao estádio de desenvolvimento das plantas, com mudanças na estrutura do dossel, havendo alteração na participação dos componentes lâmina foliar, colmo e material morto. Esses componentes estruturais determinam a qualidade da forragem, havendo redução no valor nutritivo da mesma com o aumento da massa seca disponível, em função de mudanças nas proporções de material verde e senescente das plantas (Moraes \& Maraschin, 1988; Bortolo, 1999).

Os valores médios para PBL foram sempre superiores aos da $\mathrm{PBC}$, corroborando os resultados reportados por Gerdes et al. (2000) e Rego (2001), ao trabalharem com o mesmo cultivar. Isso indica, portanto, que a produção animal pode ser otimizada com práticas de manejo do capim-Tanzânia que resultem em alta densidade de lâminas foliares verdes, especialmente no estrato mais pastejado pelos animais (Figuras 1 e 2).

A concentração de fibra em detergente neutro nas lâminas foliares (FDNL) apresentou comportamento quadrático $(\mathrm{P}<0,05)$ com o avanço na altura do dossel (Figura 3). Resultados semelhantes foram encontrados por Rego (2001) para o capim-Tanzânia. Para Tifton 85, Carnevalli et al. (2001) encontraram valores inferiores de FDN (64 a 67\%) para pastos mantidos mais baixos ( 5 a $10 \mathrm{~cm}$ ) quando comparados aos valores de 68 a $70 \%$ dos pastos mantidos mais altos $(15$ e $20 \mathrm{~cm})$.

R. Bras. Zootec., v.33, n.6, p.1959-1968, 2004 (Supl. 2) 


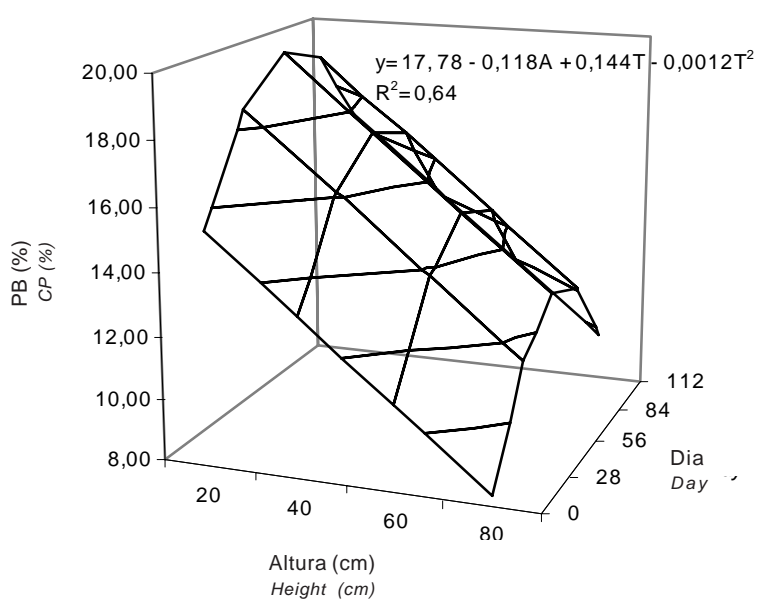

Figura 1 - Concentrações de proteína bruta nas lâminas foliares (PBL) do capim-Tanzânia, em função da altura do dossel $(A)$ e dias de avaliação $(T)$.

Figure 1 - Leaf laminae crude protein concentrations (LCP) of Tanzaniagrass, according to sward height $(A)$ and evaluation day $(T)$.

A maior concentração de FDNL, com o aumento na altura do dossel forrageiro até $60 \mathrm{~cm}$, se deve ao fato de as plantas apresentarem incremento de parede celular, uma vez que, nas maiores alturas de dossel, foram observadas lâminas mais desenvolvidas, como discutido por Cano (2002).

Para o momento de coleta, as concentrações de FDNL apresentaram comportamento linear decrescente $(\mathrm{P}<0,05)$, resposta que está associada à disponibilidade de massa de lâminas foliares, que aumentou durante o período, principalmente pelo efeito do parcelamento da adubação nitrogenada e das condições climáticas no período (Tabela 1 ), favorecendo o aumento na proporção de lâminas jovens e com menor conteúdo de parede celular (Minson, 1990; Van Soest, 1994).

A concentração de fibra em detergente neutro em colmos + bainhas (FDNC) teve efeito linear crescente $(\mathrm{P}<0,05)$ com o aumento na altura do dossel, e quadrático $(\mathrm{P}<0,05)$ ao longo dos dias de coleta (Figura 4).

O aumento nas concentrações de FDNC com o incremento na altura do dossel, segundo Minson (1990), pode ser em função da estrutura morfológica da planta e do seu maior conteúdo de parede celular. A redução das concentrações de FDNC no período intermediário (56 dias) pode ser atribuída ao rebaixa-

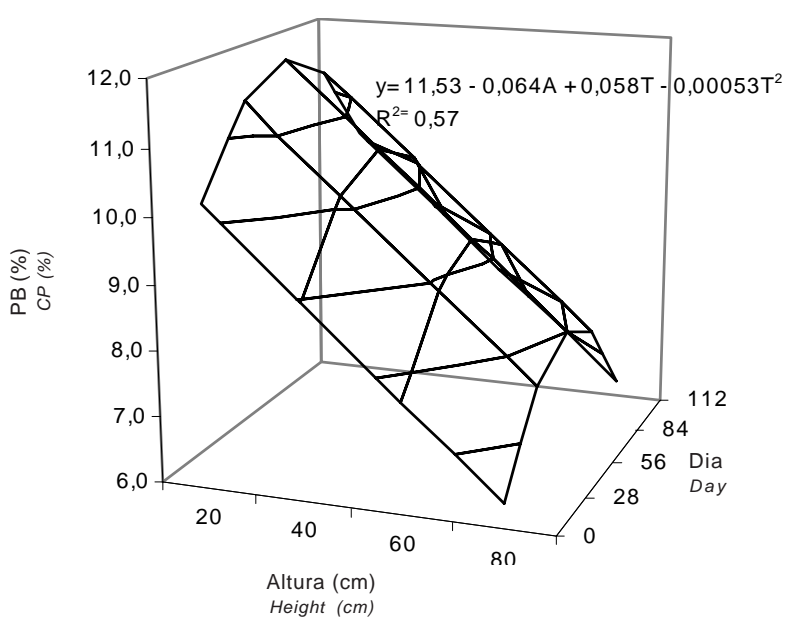

Figura 2 - Concentrações de proteína bruta nos colmos + bainhas (PBC) do capim-Tanzânia, em função da altura do dossel $(A)$ e dias de avaliação $(T)$.

Figure 2 - Stem + sheath crude protein concentrations (SCP) of Tanzaniagrass, according to sward height $(A)$ and evaluation day $(T)$.

mento do pasto nesta época, o que pode ter promovido maior remoção de forragem, com conseqüente eliminação de meristema apical e morte de perfilhos, favorecendo, na data da coleta, o aumento na proporção de perfilhos jovens, com menores teores de FDN nos colmos.

A fibra em detergente ácido nas lâminas foliares (FDAL) apresentou comportamento linear crescente $(\mathrm{P}<0,05)$ com o aumento na altura do dossel, e quadrático $(\mathrm{P}<0,05)$ ao longo do período de coleta (Figura 5). $\mathrm{O}$ aumento nas concentrações de FDAL com o incremento da altura do dossel evidencia o efeito do envelhecimento das lâminas foliares não pastejadas (Cano, 2002), justificando o aumento nas concentrações de FDA com o desenvolvimento da forragem.

Para o período de coleta, as concentrações de FDAL apresentavam-se inicialmente altas, reduzindo no período intermediário e aumentando novamente ao final da avaliação. Provavelmente, a redução nas concentrações de FDAL no período intermediário esteja associada aos efeitos da adubação nitrogenada, mantendo condições para a manutenção do crescimento do pasto e favorecendo maior presença de perfilhos e folhas jovens. No trabalho realizado por Rego (2001), foi evidenciado comportamento semelhante para altura do dossel, não ocorrendo diferença relativa ao período de avaliação. 


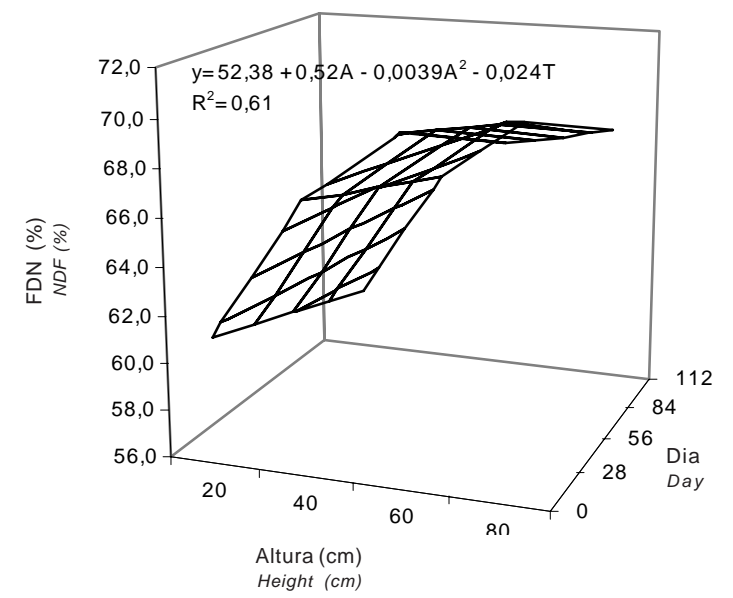

Figura 3 - Concentrações de FDN nas lâminas foliares (FDNL) do capim-Tanzânia, em função da altura do dossel (A) e do período de avaliação ( $\mathrm{T})$.

Figure 3 - Leaf blade NDF concentration (LNDF) of Tanzaniagrass, according to sward height $(A)$ and evaluation day $(T)$.

As concentrações de fibra em detergente ácido nos colmos + bainhas (FDAC), segundo as alturas de dossel, são apresentadas na Figura 6. Houve efeito linear nas concentrações de FDAC com o avanço em altura do dossel $(\mathrm{P}<0,05)$, comportamento que pode estar associado ao alongamento dos entrenós, como discutido por Cano (2002). Em capim-elefante anão cv. Mott sob pastejo contínuo, Almeida et al. (2000) observaram que as concentrações de FDA evoluíram linearmente com as ofertas de forragem, com valores médios superiores em colmos + bainhas, quando comparados às folhas. Carnevalli et al. (2001) observaram acréscimo nas concentrações de FDA com o avanço na altura do dossel de 5 para $20 \mathrm{~cm}$. Durante o período de coleta, não foi observada diferença $(\mathrm{P}>0,05)$ para as concentrações de FDAC, contrariando os resultados obtidos por Rego (2001).

As concentrações de FDAL (Figura 5) para altura de dossel forrageiro e período de coleta foram sempre inferiores às observadas para FDAC (Figura 6 ), comportamento explicado pelos constituintes de parede celular das frações folha e colmo (Minson, 1990; Van Soest, 1994).

A digestibilidade in vitro da matéria seca das lâminas foliares (DIVMSL) apresentou correlação linear negativa $(\mathrm{P}<0,05)$ com a altura do dossel (Figura 7).

\section{R. Bras. Zootec., v.33, n.6, p.1959-1968, 2004 (Supl. 2)}

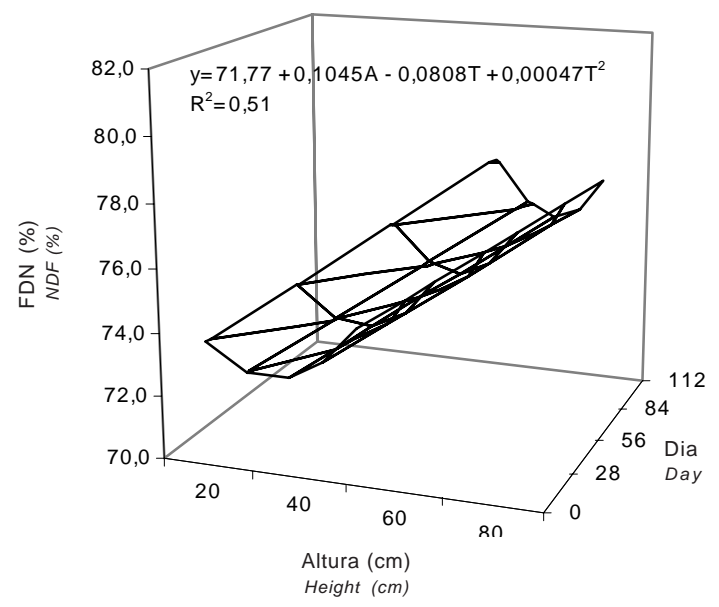

Figura 4 - Concentração de FDN em colmos + bainhas (FDNC) do capim-Tanzânia, em função da altura do dossel $(A)$ e do período de avaliação $(\mathrm{T})$.

Figure 4 - Stem + leaf sheath NDF concentration (SNDF) of Tanzaniagrass, according to sward height $(A)$ and evaluation day $(T)$.

A redução da DIVMSL com o avanço na altura do dossel está associada à manutenção do pasto mais baixo, favorecendo a constante rebrotação, com manutenção de folhas e perfilhos jovens, enquanto, em pastos mais altos, há manutenção de folhas em fase de maturação. Isso é evidenciado pelo aumento de FDN e FDA na fração lâmina com a maior altura do dossel (Figuras 3 e 5). Os valores médios estimados para DIVMS foram 74,1 e 67,0 para as alturas de dossel de 20 e $80 \mathrm{~cm}$, respectivamente. Não foi encontrada variação $(\mathrm{P}>0,05)$ na DIVMSL em função do período de avaliação. Os resultados foram contrários aos obtidos por Rego (2001), que não encontrou variação na DIVMS de lâminas foliares do capim-Tanzânia, em resposta às alturas do dossel forrageiro estudadas.

A digestibilidade in vitro da matéria seca de colmos + bainhas (DIVMSC) variou linear enegativamente $(\mathrm{P}<0,05)$ com a altura do dossel (Figura 8). Isto ocorreu por as plantas produzirem colmos mais grossos, de maior diâmetro, mais velhos e mais lignificados, reduzindo a digestibilidade dos mesmos (Cano, 2002), e em função do aumento nas concentrações de FDNC.

Entretanto, a DIVMSC aumentou linearmente $(\mathrm{P}<0,05)$ com o avanço do período de amostragem. Em parte, este comportamento é explicado pelos mesmos efeitos que ocorreram com as concentra- 


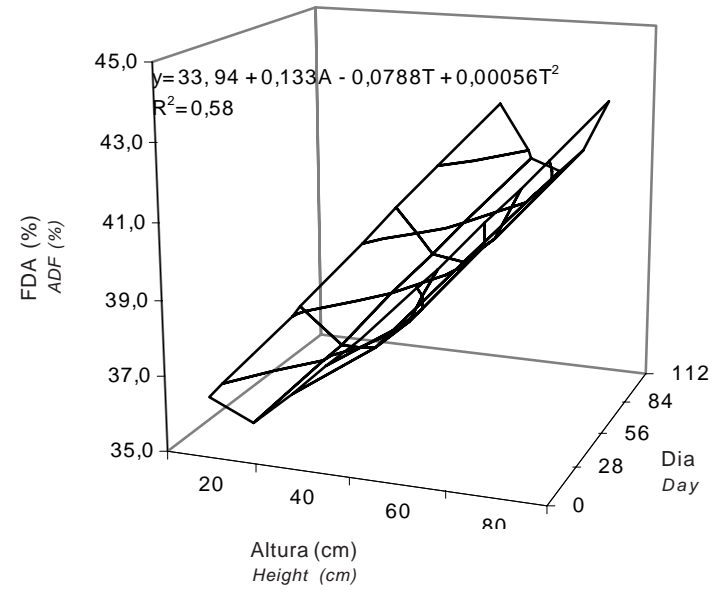

Figura 5 - Concentração de FDA nas lâminas foliares (FDAL) do capim-Tanzânia, em função da altura do dossel $(A)$ e período de avaliação (T).

Figure 5 - Leaf blade ADF concentration (LADF) of Tanzaniagrass according to sward height $(A)$ and evaluation day $(T)$.

ções de PB. Os resultados demostraram que a DIVMSL para altura do dossel e para período de avaliação foram sempre superiores a DIVMSC. Como as folhas são o principal componente da dieta animal em termos qualitativos, o manejo do pastejo deve ser orientado no sentido de manter elevada proporção de lâminas foliares na pastagem.

As concentrações de fósforo (P) nas lâminas e em colmos + bainhas diminuíram $(\mathrm{P}<0,05)$, com o avanço na altura do dossel e apresentaram compor-

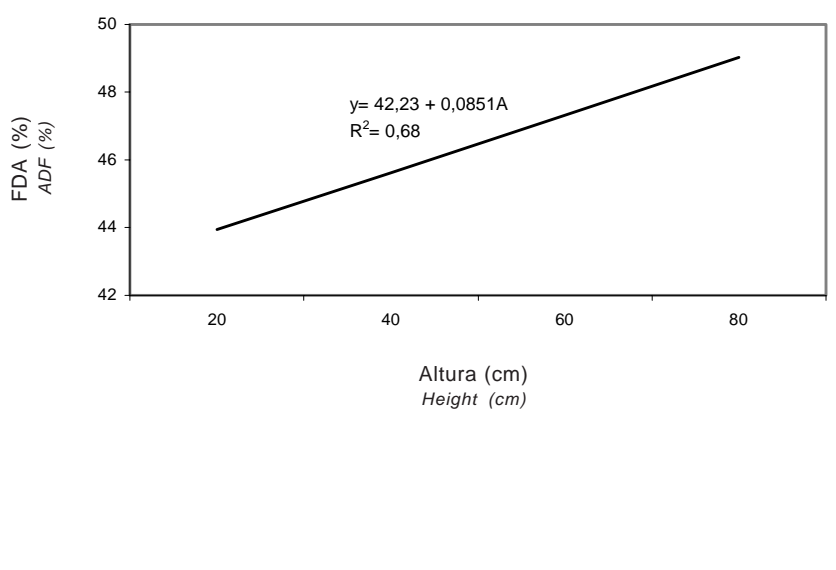

Figura 6 - Concentração de FDA nos colmos + bainhas (FDAC) do capim-Tanzânia, em função da altura do dossel (A).

Figure 6 - Stem + leaf sheath ADF levels (SADF) of Tanzaniagrass, according to sward height $(A)$.

tamento quadrático $(\mathrm{P}<0,05)$, ao longo dos dias de avaliação (Tabela 2). As concentrações mais elevadas de $\mathrm{P}$, tanto nas lâminas foliares como nos colmos, nos pastos manejados mais baixos, decorreram da idade mais jovem dessas plantas (Gomide, 1976). Nos pastos mantidos mais baixos, foi encontrada maior porcentagem de folhas jovens que em pastos mantidos mais altos (Cano, 2002).

Quanto ao momento de coleta, inicialmente as plantas apresentavam menor concentração de $\mathrm{P}$,

Tabela 2 - Equações de regressão e coeficientes de determinação $\left(R^{2}\right)$ ajustados aos teores de $P$, Ca, $M g$ e K, em função da altura do dossel (A) e/ou do período de avaliação $(T)$

Table 2 - Regression equations and coefficients of determination $\left(R^{2}\right)$ fitted to in function of pasture height $(H)$ and/or evaluation day $(T)$

\begin{tabular}{lcc}
\hline $\begin{array}{l}\text { Variável } \\
\text { Variable }\end{array}$ & $\begin{array}{c}\text { Equação de regressão } \\
\text { Regression equation } \\
\text { Lâminas foliares } \\
\text { Leaf blade }\end{array}$ & $\mathrm{R}^{2}$ \\
\hline $\mathrm{P}(\%)$ & $\hat{\mathrm{Y}}=0,447-0,0009 \mathrm{~A}+0,0015 \mathrm{~T}-0,000013 \mathrm{~T}^{2}$ & \\
$\mathrm{Ca}(\%)$ & $\hat{\mathrm{Y}}=0,626-0,006 \mathrm{~A}+0,0043 \mathrm{~T}-0,00003 \mathrm{~T}^{2}$ & 0,60 \\
$\mathrm{Mg}(\%)$ & $\hat{\mathrm{Y}}=0,28-0,00086 \mathrm{~A}+0,00093 \mathrm{~T}-0,0000055 \mathrm{~T}^{2}$ & 0,55 \\
$\mathrm{~K}(\%)$ & $\hat{\mathrm{Y}}=2,508+0,0032 \mathrm{~A}+0,00495 \mathrm{~T}-0,000448 \mathrm{~T}^{2}$ & 0,52 \\
\hline \multicolumn{4}{c}{ Colmos + bainhas } \\
\hline $\mathrm{P}(\%)$ & Stem + leaf sheath & 0,30 \\
$\mathrm{Ca}(\%)$ & $\hat{\mathrm{Y}}=0,41-0,00079 \mathrm{~A}+0,001 \mathrm{~T}-0,0000089 \mathrm{~T}^{2}$ \\
$\mathrm{Mg}(\%)$ & $\hat{\mathrm{Y}}=0,268-0,0029 \mathrm{~A}+0,0023 \mathrm{~T}-0,000018 \mathrm{~T}^{2}$ & 0,40 \\
$\mathrm{~K}(\%)$ & $\hat{\mathrm{Y}}=0,28-0,00098 \mathrm{~A}+0,0009 \mathrm{~T}-0,000006 \mathrm{~T}^{2}$ & 0,29 \\
\hline
\end{tabular}

R. Bras. Zootec., v.33, n.6, p.1959-1968, 2004 (Supl. 2) 


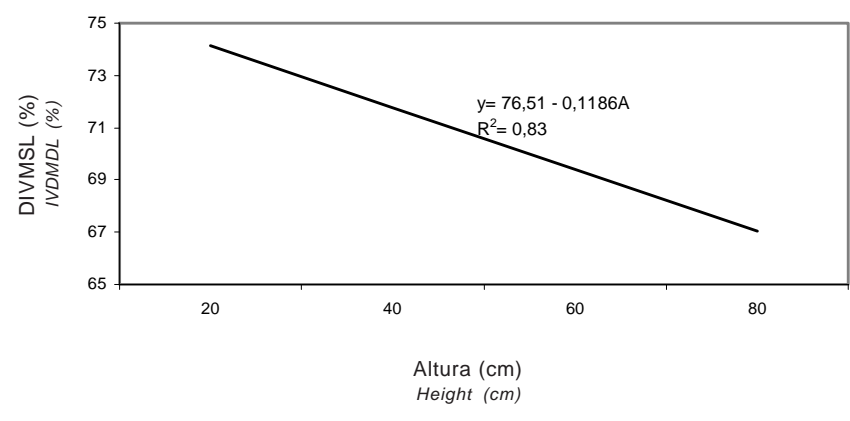

Figura 7 - Digestibilidade in vitro das lâminas foliares (DIVMSL) do capim-Tanzânia, em função da altura do dossel $(A)$.

Figure 7 - Leaf blade in vitro digestibility (IVDMDL) of Tanzaniagrass, according to sward heigh (A).

tanto na lâmina como no colmo, para todas as alturas, com elevação no período intermediário e redução no final. A redução das concentrações no período final pode ser explicada pela diminuição da precipitação (Tabela 1), posto que a água constitui-se em veículo natural para o movimento dos íons no solo, o que, provavelmente, pode ter proporcionado redução na capacidade de absorção deste elemento e na disponibilidade do mesmo no solo (Gomide, 1976). As concentrações de P na lâmina foliar e no colmo foram superiores às encontradas por Almeida et al. (2000), em capim-elefante anão cv. Mott, e próximas às observadas por Rego (2001), em capimTanzânia. Para grama Bermuda Florakirk em diferentes idades de crescimento, Vieira et al. (1999) observaram redução nas concentrações de $\mathrm{P}$ na forragem com o aumento da idade de crescimento.

Neste estudo, as concentrações médias de $\mathrm{P}$ nas lâminas foram adequadas para atender às exigências de animais em terminação (NRC, 1996). Embora as concentrações de P para lâminas foliares e colmos sejam consideradas altas em relação aos dados disponíveis na literatura, deve-se ressaltar que, neste trabalho, a quantidade de adubação fosfatada aplicada foi elevada. Portanto, pesquisas são necessárias para determinar quanto desse elemento está disponível ao animal para predizer a real necessidade de suplementação mineral em pastejo.

\footnotetext{
R. Bras. Zootec., v.33, n.6, p.1959-1968, 2004 (Supl. 2)
}

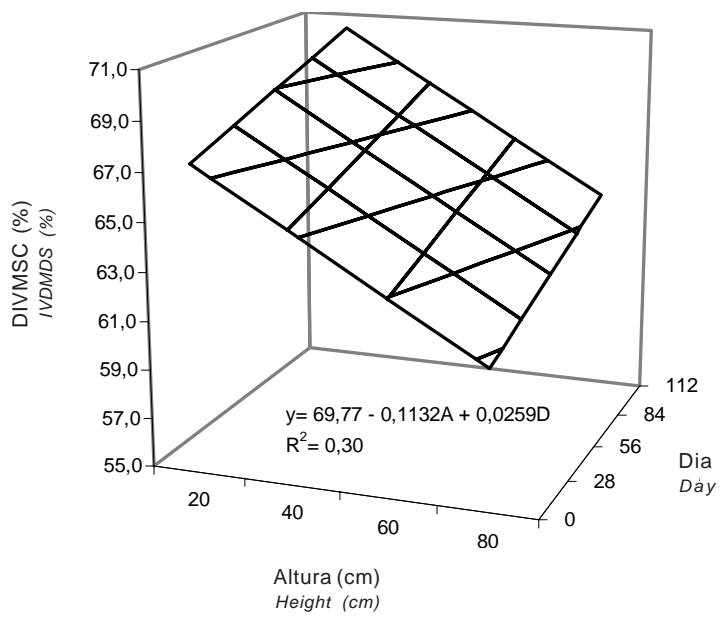

Figura 8 - Digestibilidade in vitro dos colmos + bainhas (DIVMSC) do capim-Tanzânia, em função da altura do dossel (A) e do período de avaliação (T).

Figure 8 - Stem + leaf sheath in vitro digestibility (IVDMDS) of Tanzania grass, according to sward height $(A)$ and evaluation day $(T)$.

As concentrações de cálcio (Ca) nas lâminas foliares e nos colmos + bainhas diminuíram $(\mathrm{P}<0,05)$ com o aumento em altura do dossel e apresentaram efeito quadrático $(\mathrm{P}<0,05)$ para o período de coleta (Tabela 2). Assim como para o P na lâmina foliar, os pastos mantidos em alturas menores apresentaram maior concentração de Ca tanto na lâmina foliar quanto no colmo, com redução à medida que se elevou a altura do dossel. Esse comportamento pode estar associado ao avanço na maturidade nas plantas, pois, segundo Gomide (1976), a menor concentração de minerais com o avanço na maturidade das plantas deve-se, provavelmente, ao efeito de diluição dos mesmos na matéria seca produzida e acumulada.

As concentrações de Ca na lâmina foliar em pastos mais baixos foram cerca de duas vezes superiores àquelas de pastos mais altos, com concentrações médias variando de $0,60 \%$ e $0,23 \%$ para as alturas de dossel de 20 e $80 \mathrm{~cm}$, respectivamente. Rego (2001), trabalhando com capim-Tanzânia manejado em diferentes alturas de dossel sob pastejo com lotação contínua, encontrou valores similares aos observados neste trabalho.

Embora o comportamento para altura do dossel e para período de coleta tenha sido semelhante, pode-se constatar (Tabela 2) que as concentrações de Ca na lâmina foliar foram superiores às concentrações de Ca no colmo. 
As concentrações de magnésio $(\mathrm{Mg})$ nas lâminas foliares e nos colmos + bainhas estão descritas nas equações presentes na Tabela 2. Os avanços na altura do dossel geraram redução $(\mathrm{P}<0,05)$ nas concentrações de Mg tanto na lâmina foliar como no colmo. Quanto ao período de avaliação, o comportamento foi quadrático $(\mathrm{P}<0,05)$. Os valores médios observados foram semelhantes aos encontrados por Rego (2001). Assim como para os demais nutrientes avaliados, as concentrações encontradas nas lâminas foliares foram sempre superiores às de colmos + bainhas.

As concentrações de potássio (K) nas lâminas foliares aumentaram $(\mathrm{P}<0,05)$ com a altura do dossel (Tabela 2). Dos minerais avaliados, o $\mathrm{K}$ foi o único cuja concentração elevou com o aumento da altura do dossel. Para o período, o comportamento foi semelhante ao dos outros minerais, com resposta quadrática $(\mathrm{P}<0,05)$.

O potássio não faz parte de composto orgânico algum, portanto não desempenha papel estrutural na planta (Werner, 1986). No entanto, tem ação fundamental no metabolismo vegetal. Assim, o comportamento encontrado para esse mineral foi contrário à provável função na planta, uma vez que os pastos mantidos mais baixos apresentam folhas mais jovens - mais ativas fotossinteticamente que as folhas mais velhas.

A concentração de potássio nos colmos + bainhas apresentaram comportamento linear crescente $(\mathrm{P}<0,05)$ para altura do dossel e para período de coleta (Tabela 2). Pelas equações (Tabela 2), pode-se observar que o $\mathrm{K}$ foi o único mineral que apresentou concentrações mais elevadas na fração colmos + bainhas em relação às lâminas foliares. Rego (2001) não observou diferença nas concentrações de K nos colmos em relação às alturas de manejo do capim-Tanzânia. Entretanto, para o momento de coleta, houve queda nas concentrações de $\mathrm{K}$ dos colmos.

As concentrações de minerais e sua disponibilidade nas plantas forrageiras variam em decorrência de fatores como adubação, idade da planta, estação do ano, disponibilidade do nutriente no solo, diferenças entre espécies e variedades (Gomide, 1976). Assim, é importante a determinação da concentração dos principais minerais ao longo do ano, considerando que animais em pastejo estão aptos a selecionar uma dieta de melhor qualidade que a média do pasto ofertado.

R. Bras. Zootec., v.33, n.6, p.1959-1968, 2004 (Supl. 2)

\section{Conclusões}

Independentemente da altura do dossel forrageiro e do período de avaliação estudados, o valor nutritivo das lâminas foliares foi melhor que o encontrado para colmos + bainha, indicando que o manejo do pasto deve ser direcionado à contribuição da massa de forragem de folhas.

Aumento da altura do dossel forrageiro promoveu a redução do valor nutritivo, em termos da DIVMS e de $\mathrm{PB}$, e das concentrações de minerais e o incremento dos teores de fibra (FDN e FDA) da lâmina foliar e colmo + bainha.

Mantido sob pastejo entre 40 e $60 \mathrm{~cm}$, o capimTanzânia apresentou composição química e digestibilidade de matéria seca mais compatíveis com os de uma forragem de bom valor nutritivo.

\section{Literatura Citada}

ALMEIDA, E.X.; MARASCHIM, G.E.; HARTHMANN, O.E.L. et al. Oferta de forragem de capim-elefante anão "Mott" e Rendimento animal. Revista Brasileira de Zootencia, v.29, n.5, p. 1288-1295, 2000.

BARNES, R.F. Infra-red reflectance spectroscopy for evaluating forages. In: WHEELER, J.R.; MOCHRIE, R.D. (Eds.) Forage evaluation: concepts and techniques. Netley: Griffin Press Liited. 1 ed., 1980. p.89-102.

BORTOLO, M. Avaliação de pasto de coastcross-1 (Cynodon dactylon (L.) Pers.) em níveis de matéria seca sob pastejo. Maringá: Universidade Estadual de Maringá, 1999. 75p. Dissertação (Mestrado em Zootecnia) - Universidade Estadual de Maringá, 1999.

CANO, C.C.P. Produção, dinâmica de perfilhamento e qualidade do capim-Tanzânia-1 (Panicum maximum Jacq) pastejado em diferentes alturas. Maringá: Universidade Estadual de Maringá, 2002. 90p. Dissertação (Mestrado em Zootecnia) Universidade Estadual de Maringá, 2002.

CANTO, M.W.; CECATO, U.; PETERNELLI, M. et al. Efeito da altura do capim-Tanzânia diferido nas características da pastagem no período do inverno. Revista Brasileira de Zootecnia, v.30, n.4, p.1186-1193, 2001.

CARNEVALLI, R.A.; SILVA, S.C.; FAGUNDES, J.L. et al. Desempenho de ovinos e respostas de pastagens de Tifton 85 (Cynodon spp.) sob lotação contínua. Scientia Agricola, v.58, n.1, p.7-15, 2001.

CECATO, U. Influência da frequência de corte, níveis e formas de aplicação do nitrogênio sobre a produção, composição química e algumas características da rebrota do capim Aruana (Panicum maximum Jacq. cv. Aruana). Jaboticabal, Universidade Estadual Paulista, 1993.112p. Tese (Doutorado em Produção Animal) - Universidade Estadual Paulista, 1993.

CORRÊA, A.R. Forrageiras: aptidão climática do Estado do Paraná. In: MONTEIRO, A.L.G.; MORAES, A.; CORRÊA, E.A.S. et al. (Eds.) Forragicultura no Paraná. Londrina: CPAF, 1996. p.15-22. 
EMPRESA BRASILEIRA DE PESQUISA E AGROPECUÁRIA - EMBRAPA. Centro Nacional de Pesquisa de Solos (Rio de Janeiro, RJ). Sistema brasileiro de classificação de solos. Brasília: Embrapa Produção de Informação e Rio de Janeiro: Embrapa Solos, 1999. 412p.

EUCLIDES, V. P. B.; MACEDO, M.C.M.; ZIMMER, A.H. et al. Valores nutritivos de cinco gramíneas sob pastejo. In: REUNIÃO ANUAL DA SOCIEDADE BRASILEIRA DE ZOOTECNIA, 33., 1996, Fortaleza. Anais... Fortaleza: Sociedade Brasileira de Zootecnia, 1996. p.90-92.

GERDES, L.; WERNER, J.C.; COLOZZA, M. T. et al. Avaliação de características de valor nutritivo das gramíneas forrageiras Marandu, Setária e Tanzânia nas estações do ano. Revista Brasileira de Zootecnia, v.29, n.4, p.955-963, 2000.

GOMIDE, J.A. Composição mineral de gramíneas leguminosas forrageiras tropicais. In: SIMPÓSIO LATINO-AMERICANO SOBRE PESQUISA EM NUTRIÇÃO MINERAL DE RUMINANTES E PASTAGENS, 1., 1976, Belo Horizonte. Anais... Belo Horizonte: EPAMIG, 1976. p.20-33.

HEPP, C.; MILNE, J.A.; ILLIUS, A.W. et al. The effect of summer management of perennial ryegrass-dominant swards on plant and animal responses in the autumn when grazed by sheep. 1 . Tissue turnover and sward structure. Grass and Forage Science, v.51, n.3, p.250-259, 1996.

HODGSON, J. Grazing management. Science into practice. Palmerston North: Longman, 1990. 203p.

MACHADO, A.O.; CECATO, U.; MIRA, R.T. et al. Avaliação da composição química e digestibilidade in vitro da matéria seca de cultivares e acessos de Panicum maximum Jacq. sob duas alturas de corte. Revista Brasileira de Zootecnia, v.27, n.5, p.1057-1063, 1998.

MINSON, D.J. Forage in ruminant nutrition. San Diego: Academic Press, 1990. 483p.

MORAES, A.; MARASCHIN, G. E. Pressões de pastejo e produção animal em milheto cv. comum. Pesquisa Agropecuária Brasileira, v.23, n.2, p.197-205, 1988.

MOTT, G.O.; LUCAS, H. L. The design, conduct and interpretation of grazing trials on cultivated and improved pastures. In: INTERNATIONAL GRASSLAND CONGRESS, 6., 1952, Pensylvania. Proceedings... Pensylvania: State College Press, 1952. p.1380-1385.
NATIONAL RESEARCH COUNCIL - NRC. Nutrients requeriments of beef cattle. 5.ed. Washington: National Academy of Science, 1996. 56p.

REGO, F.C.A. Avaliação da qualidade, densidade e características morfológicas do capim-Tanzânia (Panicum maximum Jacq cv. Tanzânia-1) manejado em diferentes alturas, sob pastejo. Maringá: Universidade Estadual de Maringá, 2001. 90p. Dissertação (Mestrado em Zootecnia) Universidade Estadual de Maringá, 2001.

SANTOS, G.T.; ASSIS, M.A.; PETIT, H.V. et al. Chemical composition and in sittu degradability of leucaena (Leucaena leucocephala) and desmodium (Desmodium ovalifolium) submeted at two conservation formes. Journal of Dairy Science, v.80, suppl.1, p.221, 1997.

SILVA, D.J. Análise de alimentos (métodos químicos e biológicos) 2 ed. Viçosa, MG: Universidade Federal de Viçosa, 1990. 165p.

UNIVERSIDADE FEDERAL DE VIÇOSA - UFV. Sistema para análises estatísticas e genéticas - SAEG. Viçosa, MG: 1993.

Van SOEST, P. J. Nutritional ecology of the ruminant. 2.ed. New York: Cornell University, 1994. 475p.

VIEIRA, A.C.; HADDAD, C.M.; CASTRO, F.G.F. et al. Produção e valor nutritivo da grama bermuda Florakirk (Cynodon dactylon (L.) Pers) em diferentes idades de crescimento. Scientia Agrícola, v.56, n.4, p.1185-1191, 1999.

WERNER, J.C. Adubação de pastagens. Nova Odessa: Instituto de Zootecnia, 1986. p.49. (Boletim Técnico 18)

ZIMMER, A.H. Efeito de níveis de nitrogênio e resíduos de pastejo, sobre a produção, estrutura e qualidade das cultivares Aruana e Vencedor de (Panicum maximum Jacq.). Jaboticabal: Universidade Estadual Paulista, 1999. 213p. Tese (Doutorado em Zootecnia) - Universidade Estadual Paulista, 1999. 